\title{
The Relationship of Agmatine Deficiency with the Lung Cancer
}

\author{
Serkan KAPANCIK ${ }^{1}$, V. Kenan CELIK ${ }^{1}$, Saadettin KILICKAP ${ }^{2}$, \\ Turgut KACAN ${ }^{3}$, Sercan KAPANCIK ${ }^{1}$ \\ ${ }^{1}$ Cumhuriyet University School of Medicine, Department of Biochemistry, Sivas \\ ${ }^{2}$ Hacettepe University School of Medicine, Department of Preventive Oncology, Ankara \\ ${ }^{3}$ Afyonkarahisar State Hospital, Department of Medical Oncology, Afyon, TURKEY
}

\begin{abstract}
The polyamines are essential for rapidly growing cells. Polyamines is synthesized by two reactions which begin from arginine. The aim of this study is to examine the serum levels of the enzymes located in the putrescine synthesis pathway and their relationship with lung cancer. In addition, the study also aim determine the oxidant-antioxidant status and the oxidative stress index. This study was performed on 36 lung cancer patients and 36 healthy controls. The arginase activity and the ornithine level were determined spectrophotometrically while the arginine decarboxylase, ornithine decarboxylase and agmatinase levels were determined by using Enzyme Linked Immunosorbent Assay (Elisa kit). The total antioxidant (TAS) and total oxidant status (TOS) were determined using a commercial kit auto analyser, oxidative stress index (OSI) was subsequently estimated. We observed an increase in ornithine decarboxylase, agmatinase and arginase levels in cancer patients $(p<0.05)$. however, no significant difference was observed between the two groups with regards to orithine and arginase decarboxylase levels ( $p>0.05)$. In the patient group, the TAS values decreased $(p<0.05)$, while the TOS values increased ( $p<0.05)$. In addition, the OSI values increased $(p<0.05)$. Reduced agmatine level can cause an increase in polyamine synthesis and cell proliferation. For this reason, lung cancer prognosis may have a relationship with the agmantine levels.
\end{abstract}

Keywords: Lung Cancer, Polyamine, Arginase, Ornithine, Arginine decarboxylase, Ornithine decarboxylase, Agmatinase

ÖZET

\section{Agmatin Eksikliğinin Akciğer Kanseriyle ílişkisi}

Poliaminler, hızlı bir şekilde büyüyen hücrelerde esansiyeldir. Poliaminlerin oluşumu, arjininden başlayan iki farklı reaksiyon ile gerçekleşir. Bu çalısmadaki amaç, putresin sentez yolunda görev alan enzimlerin serum düzeylerini incelemek ve akciğer kanseri ile olan ilişkisini ortaya koymaktır. Ayrıca, oksidan-antioksidan kapasite ve oksidatif stress indeksini saptamaktır. Bu çalısmaya 36 akciğer kanseri hastası ve 36 sağlıklı kontrol dahil edildi. Arjinaz aktivitesi ve ornitin düzeyi spektrofotometrik olarak ve arjinin dekarboksilaz, ornitin dekarboksilaz, agmatinaz düzeyleri ise elisa kiti kullanılarak tayin edildi. Total antioksidan (TAS) ve total oksidan kapasite (TOS) ticari kit kullanılarak otoanalizörde saptandı. Ve oksidatif stress indeksi (OSi) hesaplandı. Çalışmada akciğer kanserli hastaların serumlarında ornitin dekarboksilaz, agmatinaz ve arjinaz düzeylerinde artış gözlendi $(p<0.05)$. Ornitin ve arjinin dekarboksilaz düzeyleri bakımından iki grup arasında istatistiksel olarak anlamlı bir fark saptanmamışıı ( $p>0.05)$. Hasta grubunda TAS değerleri düştü $(p<0.05)$, TOS değerleri arttı ( $p<0.05)$. Buna bağlı olarak OSi değerleri de arttı $(p<0.05)$. Azalmış agmatin düzeyi, poliamin sentezinde ve proliferasyonda artışa neden olabilir. Bundan dolayı akciğer kanserinin prognozu ile agmatin düzeyleri birebir ilişkili olabilir.

Anahtar Kelimeler: Akciğer Kanseri, Poliamin, Arjinaz, Ornitin, Arjinin Dekarboksilaz, Ornitin Dekarboksilaz, Agmatinaz 


\section{INTRODUCTION}

Lung cancer is the most prevalent of cancer deaths in the world (1/5th of the deaths realised due to cancer, is from lung cancer). Due to the occurrence of approximately 1.8 million new lung cancer cases per year, it is noted to be the most prevalent cancer type. ${ }^{1}$ Therefore, understanding the mechanisms of lung cancer, is important in the treatment of this disease.

The accumulation of polyamines in the tissues increase the proliferation of cells and even has a contribution in bacterial proliferation. In recent years, as a result of the aforementioned properties of polyamines, they have become a subject of research with regards to neoplastic tissues. ${ }^{2}$

The polyamines play an important role in many different biological processes such as the regulation of ion channels, enzyme activities, translation and transcription. At the same time, the polyamines constitute a response to oxidative stress and increase the mRNA levels which are necessary for protein biosynthesis by forming hypusine..$^{3-6}$ The regulation of the polyamine levels in the tumour cells are frequently disrupted., 5 The polyamine levels are found to be particularly higher in rapidly proliferating cells. ${ }^{5,7,8}$ In studies that have been made, it was reported that the level of polyamine frequently increased in the urine and blood of breast, colon, lung, prostate and skin cancer patients. In a previous analyses carried out on cancer patients, it was observed that the major polyamines(putrescine, spermidine, spermine) and the acetylated forms of these were increased and accumulated. ${ }^{9-15}$ In addition, the relationship between the inhibition of polyamine sythesis and cancer theraphy are currently being investegated. ${ }^{10}$ It was shown that polyamine level and the tumour size reduced with the therapy. ${ }^{16}$ This indicates that cancer cells need polyamines for growth and proliferation. For this reason, it is thought that increasing polyamines provide considerable contributions to poor prognosis of cancer. ${ }^{17-20}$

In this study, we aimed to determine the levels of arginine decarboxylase, agmatinase (it gives information about the agmatine level indirectly) from the enzymes which take charge in the synthesis of putrescine that is necessary for the synthesis of the major polyamines(spermidine, spermine), argin- ase, ornithine decarboxylase and ornithine in the serums of lung cancer patients and to put forth its relatonship with lung cancer. In addition, to examine the relationship between these parameters and oxidative stress factors.

\section{MATERIALS AND METHODS}

\section{Patient and Control Group}

The 36 patients, who were diagnosed with lung cancer and applied to Cumhuriyet University Medicine Faculty Oncology Polyclinic were included in the study. No restriction was made with respect to sex, age or the histopathologic type of cancer as well as its degree.

Our control group consisted of 36 healthy individuals who had no systemic diseases(diabetes, hypertension, lung cancer disease).

\section{Blood Samples Collection}

Blood samples were taken from the controls and lung cancer cases who were not on therapy. The serums were obtained by centrifugation at $1610 \mathrm{x}$ $\mathrm{g}$ for 10 minutes from the blood sample preserved at $-80^{\circ} \mathrm{C}$ for the study.

Ornithine, arginine decarboxylase, ornithine decarboxylase, agmatinase levels and arginase enzyme activity have been measured in serum of lung cancer patients.

Arginase activity were measured spectrophotometrically according to the method defined by Geyer and Dabich and was reported as $\mu \mathrm{mol}$ urea $/ \mathrm{mL} /$ hour. ${ }^{21}$ Ornithine level were calculated spectrophotometrically at $515 \mathrm{~nm}$ using the method defined by Chinard and was reported as $\mu \mathrm{mol} / \mathrm{ml} .{ }^{22}$

Arginine decarboxylase, ornithine decarboxylase and agmatinase levels were determined by ELISA kit according to the manufacturer's protocol (Cusabio Biotech, Wuhan, China).

The total antioxidant and the total oxidant status were determined by using commercial kit(Rel Assay Diagnostic)

\section{Statistical Analysis}

In the evaluation of data, when parametric test assumptions were fulfilled the significance test of the 
Table 1. The age ranges of lung cancer patients and controls

\begin{tabular}{|llll|}
\hline Age (in Years) & Patient (n) & Control (n) & P \\
\hline $0-50$ & 4 & 7 & \\
$51-60$ & 11 & 19 & \\
$61-70$ & 15 & 7 & \\
$>71$ & 6 & 3 & \\
\hline * Median age & $61,72 \pm 9,04$ & $57,44 \pm 15,51$ & $P=0.157$ \\
* Data expressed as mean \pm standard deviation & \\
\hline
\end{tabular}

difference between the two average was applied, the parametric test assumptions were not fulfilled the Mann Whitney U test was applied. The data was given in the tables as arithmetical average \pm Standard deviation and the level of significance was taken as less than 0,05 .

\section{RESULTS}

When the ages of the individuals in the control group (mean age $57.44 \pm 15.51$ ) were compared with the ages of the individuals in the case group (mean age $61.72 \pm 9.04$ ), there was no significant difference observed $(\mathrm{p}=0.157)$ (Table 1). Also, there was no significant difference observed between gender in the case and control group.

The tumor characteristics of lung cancer patients were given on Table 2 .

In our study, when individuals in the case and control groups were compared in respect to their levels of agmatinase, arginase and ornithine decarboxylase, the difference between the two groups was

\begin{tabular}{|ll|}
\hline Table 2. The tumor characteristics of lung cancer patients \\
\hline Tumor Histology and Stage & Patient (n) \\
\hline $\begin{array}{l}\text { Adenocarcinoma } \\
\text { Localised }\end{array}$ & 0 \\
$\quad$ Locally Advanced & 3 \\
$\quad$ Metastatic & 8 \\
Squamous cell carcinoma & \\
$\quad$ Localised & 0 \\
$\quad$ Locally Advanced & 11 \\
$\quad$ Metastatic & 7 \\
Small cell lung cancer & \\
Localised & 0 \\
Locally Advanced & 1 \\
Metastatic & 4 \\
Non-small cell lung cancer & \\
Localised & 0 \\
Locally Advanced & 1 \\
Metastatic & 1
\end{tabular}

statistically significant $(p=0.001)$ The increase in the enzyme levels were compared in accordance to the control group, respectively agmatinase was $300 \%$, arginase was approximately $200 \%$ and ornithine decarboxylase was $100 \%$. Statistically, there was no significant difference between the two groups with regard to their ornithine and arginine decarboxylase levels(respectively, $\mathrm{p}=0.860$ and $\mathrm{p}=$ 0.424) (Table 3).

Also in our study, when individuals in the case and control groups were compared with regard to total antioxidant status, total oxidant status and oxidative stress index, the difference between the two groups was statistically significant (respectively, $\mathrm{p}=0.002, \mathrm{p}=0.001$ and $\mathrm{p}=0.001)$ When these pa-

\begin{tabular}{|c|c|c|c|}
\hline & Patient ( $n=36$ ) & Control ( $n=36$ ) & $\mathbf{p}$ \\
\hline${ }^{\star \star}$ Arginine Decarboxylase (pg/ml) & $206.36 \pm 109.66$ & $191.01 \pm 126.67$ & 0.424 \\
\hline **Ornithine Decarboxylase (pg/ml) & $225.47 \pm 122.40$ & $130.29 \pm 70.42$ & 0.001 \\
\hline ^^Agmatinase (pg/ml) & $967.72 \pm 769.89$ & $233.70 \pm 109.88$ & 0.001 \\
\hline${ }^{\star \star}$ Arginase ( $\mu \mathrm{mol}$ urea/ml/hour) & $23.88 \pm 19.58$ & $7.38 \pm 3.91$ & 0.001 \\
\hline *Ornithine $(\mu \mathrm{mol} / \mathrm{ml})$ & $0.08 \pm 0.02$ & $0.08 \pm 0.02$ & 0.860 \\
\hline
\end{tabular}


Table 4. The serum Total Antioxidant Status, Total Oxidant Status, Total Oxidative Index of lung cancer patients and controls

\begin{tabular}{|c|c|c|c|}
\hline & Patient ( $n=36$ ) & Control ( $n=36$ ) & $\mathbf{p}$ \\
\hline $\begin{array}{l}\text { *Total Antioxidant Status } \\
\text { (mmol/Trolox Equiv./L) }\end{array}$ & $2.20 \pm 0.53$ & $2.57 \pm 0.45$ & 0.002 \\
\hline $\begin{array}{l}{ }^{\star \star} \text { Toplam Oxidant Status } \\
\left(\mu \mathrm{mol} \mathrm{H}_{2} \mathrm{O}_{2} \text { Equiv./L) }\right.\end{array}$ & $50.93 \pm 29.72$ & $28.61 \pm 14.61$ & 0.001 \\
\hline${ }^{\star \star}$ Oxidative Stress Index & $22.72 \pm 12.32$ & $11.76 \pm 9.04$ & 0.001 \\
\hline
\end{tabular}

rameters were compared according to the control group, respectively, while the total antioxidant status was diminished by $10 \%$, the total oxidant status increased by $100 \%$. This case caused an increase of $100 \%$ in the oxidative stress index (Table 4).

\section{DISCUSSION}

It is known that there are rapid growth in the cells and tissues which have polyamine accumulation. For this reason, it plays an important role in the formation of benign and malign disease. The polyamines are necessary for protein synthesis and response to oxidative stress which exist in many diseases. The polyamine regulation is disrupted due to the enzymatic changes in cancer patients and this lead to an increase in polyamine

levels. ${ }^{4,10,23}$

In this study, when the levels of arginase and ornithine decarboxylase from the enzymes which take place in the first reaction mechanism of the putrescine formation pathway were compared according to the control group, the result revealed an increase of $200 \%$ and $100 \%$ respectively. This increase is significant statistically $(\mathrm{p}<0.05)$. In various studies that were made, it was reported that arginese activity increased different cancer types(lung, colorectal, prostate, pancreas, skin and stomach cancer. ${ }^{24-29}$ The findings in these studies support our findings.

The increased arginase activity must have caused an increase in ornithine levels according to the reaction. However, in our findings, it was determined that ornithine levels did not change when compared with the control group ( $\mathrm{p}>0.05)$. The reason for this was the increase in ornithine decar- boxylase level which took place in the continuation of the reaction. Thus, it demonstrated that ornithine which formed by the increased arginase activitity changed into putrescine. for this reason, there was no significant difference observed when the ornithine level was compared between two group.

In a study, it was reported that when ornithine decarboxylase expression on cancerous lung and the normal lung tissue was examined, the expression of the enzyme on the cancerous lung tissue increased. ${ }^{30}$ Also, it was shown that the ornithine decarboxylase expression in the other cancerous tissues such as prostate, breast, oesaphagus cancer increase. ${ }^{31-33}$ Besides, the increase of the mucosal ornithine decarboxylase enzyme activity in colorectal cancer and stomach cancer support our findings. ${ }^{34,35}$

When the enzyme levels in the second pathway taking place in the putrescine formation were compared to the control group, it was found that arginine decarboxylase levels did not change ( $p>$ 0.05 ), but the agmatinase level increased with a ratio of $300 \%(p<0.05)$. In this case, the putrescine formation increase. On the other hand, the enzyme level's raising to 4 times should be diminish the amount of agmatine which is a natural substrate of the enzyme.

In the researches that were made, it was found that agmatine inhibited cell growth and proliferation. ${ }^{36,37}$ It was also fixed that agmatine decreased polyamine synthesis by increasing the expression of antizyme that mediates the degradation of ornithine decarboxylase. ${ }^{36}$ Another effect of the agmatine on the polyamine levels was also the diminishing of putrescine, spermidine and spermine 
in the cell by increasing the spermidine-spermine acetyl transferase (SSAT) activity. ${ }^{38}$

The increase in polyamine concentration causes the increase of growth stimulation by means of increase of the transcription factors such as c-myc, cfos and c-jun expression, the decrease in polyamine level arrest the improvement of the cell-cycle. ${ }^{39-41}$ The decreasing polyamine levels stabilize the transcripts (p53, TGF- $\beta$ ve junD) of the genes which inhibited growth. ${ }^{42-44}$ The absence of spermidine causes inhibition of the hipusination. This case causes inhibition of the function of factor eukaryotic translation initiation factor 5A (elF5A) which is bounded to the hipusination and a decrease of the cell growth. ${ }^{45,46}$ The polyamine levels in different cancer patients found is high compared to the control group. ${ }^{47-48}$ These data strongly support our finding.

Oxidative stress can be defined as an increase in the oxidant molecules or a decrease in the antioxidant capacity. The increasing oxidative stress index causes the decrease in the defense capability of the organism against the oxidative damage. ${ }^{49}$ In our study, when the oxidative stress index was compared with the control group, a 100\% increase in the patient group was determined. The polyamines owned a capability of forming a response against the oxidative damage. ${ }^{50}$ According to our findings, the increasing polyamine levels did not prevent the oxidative damage.

In conclusion, the findings obtained from this pilot study suggested that the increase in the enzyme levels which take part in the putrescine formation pathway causes more putrescine by influencing the direction of the synthesis. The increasing putrescine concentration naturally cause an increase in the synthesis of spermidine and spermine from the other major polyamines. While the increase in the polyamine levels inevitably causes the uncontrolled proliferation and increasing prevalence of the cancer cells, it fails in the prevention of the oxidative damage.

The agmatine can prevent the excessive putrescine formation in the synthesis reaction mechanism. It accomplishes this through two way (its effect on the two critical enzymes). In the first, agmatine inhibit the expression of the ornithine decarboxylase enzyme in the first synthesis pathway by means of antizyme molecule. In the second, it decreases the putrescine, spermidine and spermine levels by increasing the SSAT activity.

\section{Conclusions}

The increase of polyamine synthesis which play a role in the progression of lung cancer stem from agmatine inadequacy resulting from high agmatinase levels together with the differentiated enzyme levels in the polyamine biosynthesis pathway. The reason for this is non-prevention of the increase in the amount of putrescine which is a precursor in the synthesis of other major polyamines because of remain incapable the decreased agmatine's regulating role on the putrescine formation mechanism. There is a need for studying the relationship between agmatine and cancer prognosis in other types of cancer, as well. Future studies on this subject may provide greater contribution to cancer treatment.

\section{ACKNOWLEDGEMENTS}

This study was supported by Cumhuriyet University, The Scientific Research Projects Commission. (Project No. T-540)

\section{REFERENCES}

1. http://globocan.iarc.fr/Pages/fact_sheets_cancer.aspx (Access date: 01/22/2014).

2. Bachrach U. Polyamines and cancer: minireview article. Amino Acids 26: 307-309, 2004.

3. Park MH, Joe YA, Kang KR, et al. The polyamine-derived amino acid hypusine: its posttranslational formation in elF-5A and its role in cell proliferation. Amino Acids 10: 109-121, 1996.

4. Pignatti C, Tantini B, Stefanelli C, Flamigni F. Signal transduction pathways linking polyamines to apoptosis. Amino Acids 27: 359-365, 2004.

5. Wallace HM, Fraser AV, Hughes A. A perspective of polyamine metabolism. Biochem J 376: 1-14, 2003.

6. Wang JY, Casero RA. Polyamine cell signaling: physiology, pharmacology, and cancer research. 1st edition. New Jersey, Humana Press, 2006: 349-383.

7. Nowotarski SL, Woster PM, Casero RA Jr. Polyamines and cancer: implications for chemotherapy and chemoprevention. Expert Rev Mol Med 15: 1-21, 2013.

8. Porter CW, Bergeron RJ. Spermidine requirement for cell proliferation in eukaryotic cells: structural specificity and quantitation. Science 219: 1083-1085, 1983. 
9. Russell DH, Gullino PM, Marton LJ, LeGendre SM. Polyamine depletion of the MTW9 mammary tumor and subsequent elevation of spermidine in the sera of tumor-bearing rats as a biochemical marker of tumor regression. Cancer Research 34: 2378-2381, 1974.

10. Gerner EW, Meyskens FL. Polyamines and cancer: old molecules, new understanding. Nature Reviews Cancer 4: 781792, 2004.

11. Thomas T, Thomas TJ. Polyamine metabolism and cancer. Journal of Cellular and Molecular Medicine 7: 113-126, 2003.

12. Watanabe S, Sato S, Nagase S, Ohkuma S. Chemotherapeutic choice of ranimustine or nimustine on the basis of regional polyamine levels in rat brain. Methods and Findings in Experimental and Clinical Pharmacology 30: 115-120, 2008.

13. Roy UKB, Rial NS, Kachel KL, Gerner EW. Activated K-RAS increases polyamine uptake in human colon cancer cells through modulation of caveolar endocytosis. Molecular Carcinogenesis 47: 538-553, 2008.

14. Byun JA, Lee $\mathrm{SH}$, Jung $\mathrm{BH}$, et al. Analysis of polyamines as carbamoyl derivatives in urine and serum by liquid chromatography-tandem mass spectrometry. Biomedical Chromatography 22: 73-80, 2008.

15. Giskeødegård GF, Bertilsson H, Selnæs KM, et al. Spermine and citrate as metabolic biomarkers for assessing prostate cancer aggressiveness. PLoS One 8: 1-9, 2013.

16. Verma AK. Inhibition of tumor promotion by DL- $\alpha-$ difluoromethylornithine, a specific irreversible inhibitor of ornithine decarboxylase. Basic Life Sci 52: 195-204, 1990.

17. Löser C, Fölsch UR, Paprotny C, Creutzfeldt W. Polyamines in colorectal cancer. Evaluation of polyamine concentrations in the colon tissue, serum, and urine of 50 patients with colorectal cancer. Cancer 65: 958-966, 1990.

18. Chatel M, Darcel F, Quemener V, et al. Red blood cell polyamines as biochemical markers of supratentorial malignant gliomas. Anticancer Res 7: 33-38, 1987.

19. Kubota S, Okada M, Yoshimoto M, et al. Urinary polyamines as a tumor marker. Cancer Detect Prev 8: 189-192, 1985.

20. Uehara N, Shirakawa S, Uchino H, Saeki Y. Elevated contents of spermidine and spermine in the erythrocytes of cancer patients. Cancer 45: 108-111, 1980.

21. Geyer JW, Dabich D. Rapid method for determination of arginase activity in tissue homogenates. Anal Biochem 39: 412417,1971

22. Chinard FP. Photometric Estimation of Proline and Ornithine. J Bil Chem 199: 91-95, 1952.

23. LaMuraglia GM, Lacaine F, Malt RA. High ornithine decarboxylase activity and polyamine levels in human colorectal neoplasia. Ann Surg 204: 89-93, 1986.

24. Gökmen SS, Yörük Y, Çakir E, et al. Arginase and ornithine, as markers in human nonsmall cell lung carcinoma. Canc Biochem Biophys 17: 125-131, 1999.

25. Leu SY, Wang SR. Clinical significance of arginase in colorectal cancer. Cancer 70: 733-736, 1992.
26. Harris BE, Pretlow TP, Bradley ELJ, et al. Arginase activity in prostatic tissue of patients with benign prostatic hyperplasia and prostatic carcinoma. Cancer Res 43: 3008-3012, 1983.

27. Löser C, Fölsch UR, Paprotny C, Creutzfeldt W. Polyamine concentrations in pancreatic tissue, serum, and urine of patients with pancreatic cancer. Pancreas 5: 119-127, 1990.

28. Gökmen SS, Aygit AC, Ayhan MS, et al. Significance of arginase and ornithine in malignant tumors of the human skin. $\mathrm{J}$ Lab Clin Med 137: 340-344, 2001.

29. Wu CW, Chi CW, Ho CK, et al. Effect of arginase on splenic killer cell activity in patients with gastric cancer. Dig Dis Sci 39: 1107-1112, 1994.

30. Tian $Y$, Huang $Q$, Li L, et al. Gene expression of ornithine decarboxylase in lung cancers and its clinical significance. Acta Biochimica et Biophysica Sinica 38: 639-645, 2006.

31. Mohan RR, Challa A, Gupta S, et al. Overexpression of ornithine decarboxylase in prostate cancer and prostatic fluid in humans. Clinical Cancer Research 5: 143-147, 1999.

32. Deng W, Jiang X, Mei $Y$, et al. Role of ornithine decarboxylase in breast cancer. Acta Biochimica et Biophysica. Sinica 40: 235-243, 2008.

33. Yoshida M, Hayashi H, Taira M, Isono K. Elevated expression of the ornithine decarboxylase gene in human esophageal cancer. Cancer Research 52: 6671-6675, 1992.

34. Hixson LJ, Garewal HS, McGee DL, et al. Ornithine decarboxylase and poliamines in colorectal neoplasia and mucosa. Cancer Epidemiology Biomarkers and Prevention 2: 369-374, 1993.

35. Okuzumi J, Yamane T, Kitao Y, et al. Increased mucosal ornithine decarboxylase activity in human gastric cancer. Cancer Research 51: 1448-1451, 1991.

36. Satriano J, Matsufuji S, Murakami Y, et al. Agmatine suppresses proliferation by frameshift induction of antienzyme and attenuation of cellular polyamine levels. J Biol Chem 273 15313-15316, 1998.

37. Regunathan S, Youngson C, Raasch W, et al. Imidazoline receptors and agmatine in blood vessels: a novel system inhibiting vascular smooth muscle proliferation. J Pharmacol Exp Ther 276: 1272-1282, 1996.

38. Vargiu C, Cabella C, Belliardo S, et al. Agmatine modulates polyamine content in hepatocytes by inducing spermidine/ spermine acetyltransferase. Eur J Biochem 259: 933-938, 1999.

39. Wang JY, McCormack SA, Viar MJ, et al. Decreased expression of protooncogenes c-fos, c-myc, and c-jun following polyamine depletion in IEC-6 cells. Am J Physiol Gastrointest Liver Physiol 265: 331-338, 1993.

40. Li L, Rao JN, Bass BL, Wang JY. NF-kappaB activation and susceptibility to apoptosis after polyamine depletion in intestinal epithelial cells. Am J Physiol Gastrointest Liver Physiol 280: 992-1004, 2001.

41. Stephenson AH, Christian JF, Seidel ER. Polyamines regulate eukaryotic initiation factor $4 \mathrm{E}$ binding protein 1 gene transcription. Biochem Biophys Res Commun 323: 204-212, 2004. 
42. Patel AR, Wang JY. Polyamines modulate transcription but not posttranscription of c myc and cjun in IEC-6 cells. Am J Physiol 273: 1020-1029, 1997.

43. Li L, Liu L, Rao JN, et al. JunD stabilization results in inhibition of normal intestinal epithelial cell growth through p21 after polyamine depletion. Gastroenterology 123: 764-779, 2002.

44. Li L, Li J, Rao JN, et al. Inhibition of polyamine synthesis induces p53 gene expression but not apoptosis. Am J Physiol 276: 946-954, 1999.

45. Schnier J, Schwelberger HG, Smit-McBride Z, et al. Translation initiation factor $5 \mathrm{~A}$ and its hypusine modification are essential for cell viability in the yeast Saccharomyces cerevisiae. Mol Cell Biol 11: 3105-3114, 1991.

46. Zuk D, Jacobson A. A single amino acid substitution in yeast elF-5A results in mRNA stabilization. EMBO J 17: 2914-2925, 1998.

47. Horn Y, Beal SL, Walach N, et al. Relationship of urinary polyamines to tumor activity and tumor volume in patients. Cancer Research 44: 4675-4678, 1984.

48. Kalac P. Health effects and occurrence of dietary polyamines: A review for the period 2005-mid 2013. Food Chemistry 161: 27-39, 2014.

49. Cete S, Arslan F, Yasar A. Aloe vera ve nerium oleanderin bazi mikroorganizmalara karsi antimikrobiyal aktivitenin arastirimasi ve bu bitkilerin siklosporinli karaciger dokusundaki ksantin oksidaz enzim aktivitesine etkilerinin incelenmesi. G Ü Fen Bilimleri Dergisi 18: 375-380, 2005.

50. Tkachenko A, Nesterova L, Pshenichnov M. The role of the natural polyamine putrescine in defense against oxidative stress in Escherichia coli. Arch Microbiol 176: 155-157, 2001.

\section{Correspondence}

Serkan KAPANCIK

Cumhuriyet Üniversitesi Tip Fakültesi

Biyokimya Anabilim Dali

58140, SIVAS / TURKEY

Tel: (+90-346) $2191010 / 1075$

email: serkankapancik@gmail.com 